\title{
Deep Convolutional Neural Network untuk Mendeteksi Retak pada Permukaan Beton yang MemilikiVoid
}

\author{
Patrick Nicholas Hadinata ${ }^{1 *}$, Djoni Simanta ${ }^{1}$ and Liyanto Eddy ${ }^{1}$
}

Dikirim: 22/08/2021

Diterima: 04/10/2021

\begin{abstract}
ABSTRAK
Convolutional neural network berbasis encoder-decoder telah dirancang dan dilatih menggunakan dataset eksternal untuk mendeteksi retak pada permukaan beton yang relatif sederhana. Namun, pada kenyataannya permukaan beton memiliki banyak fitur seperti void pada permukaan yang disebabkan oleh udara yang terperangkap saat proses pencampuran beton. Oleh karena itu, pada penelitian ini kemampuan convolutional neural network akan diteliti lebih lanjut untuk mendeteksi retak pada permukaan beton yang memiliki void. Tujuan pertama penelitian ini adalah menguji model yang dilatih dengan dataset eksternal pada permukaan beton ber-void. Jika model tidak berhasil membedakan void dengan retak, maka tujuan kedua penelitian ini adalah menyusun dataset pelatihan internal baru yang secara khusus membedakan void dengan retak, yang kemudian akan ditambahkan pada dataset eksternal untuk diinvestigasi performanya. Penelitian ini menggunakan arsitektur U-Net dan arsitektur DeepLabV3+ sebagai encoder-decoder untuk mengoperasikan semantic image segmentation. Model encoder-decoder yang dilatih dengan dataset eksternal tidak berhasil membedakan void dengan retak saat pengujian. Maka, dataset internal yang terdiri dari gambar beton ber-void dibentuk dan digabungkan dengan dataset eksternal. Dengan penambahan dataset internal yang baru, hasil pengujian menunjukkan bahwa model berhasil membedakan void dengan retak pada permukaan beton. U-Net mencapai nilai F1 sebesar 85,92\%, sedangkan DeepLabV3+ mencapai nilai F1 sebesar $84,09 \%$.
\end{abstract}

Kata kunci: convolutional neural network; DeepLabV3+; deteksi retak; U-Net; void

\section{PENDAHULUAN}

Deteksi retak pada permukaan beton merupakan langkah penting untuk menilai kondisi infrastruktur. Retak yang tidak terdeteksi dapat berakibat buruk pada kesehatan infrastruktur. Secara umum, deteksi retak pada permukaan beton dilakukan secara manual. Metode ini memiliki beberapa keterbatasan, yaitu biaya yang mahal, keamanan yang kurang terjamin, dan bersifat subjektif terhadap tenaga ahli. Oleh karena itu, metode yang otomatis dan lebih terukur dapat dirancang menggunakan teknik penglihatan komputer.

Convolutional neural network (CNN) merupakan salah satu metode kecerdasan buatan berbasis penglihatan komputer yang dirancang secara khusus untuk mengekstrak fitur spasial dari data gambar. Deskripsi matematika kompleks dari gambar dapat diekstrak menggunakan metode konvolusi dengan teknik sliding window. Fitur yang diekstrak dari gambar dapat disebut sebagai feature map.

Ketelitian tingkat piksel dapat dicapai menggunakan algoritme semantic image segmentation. CNN dapat disusun menjadi encoder-decoder untuk melakukan semantic image segmentation. Encoder akan melakukan downsampling pada feature map untuk mereduksi kompleksitas dimensi gambar dan menyimpan fitur penting. Decoder akan melakukan upsampling untuk

\footnotetext{
${ }^{1}$ Universitas Katolik Parahyangan, Jl. Ciumbuleuit No.94, Bandung 40141

*pnhadinata@gmail.com
} 
mengembalikan dimensi gambar menjadi ukuran semula. Hasil dari decoder adalah feature map berupa prediksi kelas masing-masing piksel pada gambar.

Terdapat banyak arsitektur encoder-decoder yang telah dikembangkan. Terdapat dua arsitektur yang populer digunakan untuk memecahkan berbagai masalah penglihatan komputer, yaitu U-Net [1] dan DeepLabV3+ [2]. U-Net memenangkan ISBI cell tracking challenge 2015 dengan nilai tertinggi. DeepLabV3+ mencapai nilai tertinggi dalam PASCAL VOC 2012 dataset dengan mloU 89\%. U-Net dan DeepLabV3+ telah dibandingkan performanya dalam bidang deteksi retak menggunakan dataset eksternal [3] dengan hasil U-Net berperforma lebih baik dari DeepLabV3+ [4]. Namun, gambar permukaan beton pada dataset eksternal memiliki fitur permukaan yang relatif sederhana, sedangkan pada kenyataannya permukaan beton seringkali memiliki fitur permukaan seperti void. Oleh karena itu, penelitian ini bertujuan untuk menginvestigasi kemampuan model yang dilatih dengan dataset eksternal dalam membedakan void dengan retak. Jika model tidak berhasil membedakan void dengan retak, maka dataset internal tambahan yang terdiri dari foto beton dengan void permukaan akan disusun untuk mengatasi keterbatasan model sebelumnya. Performa model sebelum dan sesudah penambahan dataset internal akan dibandingkan dari segi parameter evaluasi F1 dan hasil pengujian gambar. U-Net dan DeepLabV3+ juga akan dibandingkan kembali performanya setelah penambahan dataset internal yang baru.

\section{TINJAUAN PUSTAKA}

\section{Deep Learning dan Convolutional Neural Network}

Deep learning adalah kemampuan komputer untuk mempelajari pola-pola yang terdapat dari suatu kumpulan data. Deep learning banyak diterapkan pada teknik pembelajaran supervised ataupun pembelajaran unsupervised. Beberapa contoh penerapan deep learning adalah pengenalan suara, penglihatan komputer, analisis deret waktu, regresi non-linear, dan klasifikasi data. Salah satu jenis algoritme deep learning yang secara khusus disusun untuk menganalisis data gambar adalah CNN. CNN menggunakan teknik sliding window untuk mengekstrak fitur level tinggi dari gambar. Pada penelitian ini, fitur yang secara khusus akan diekstrak guna analisis gambar adalah fitur retak pada permukaan beton.

\section{Arsitektur U-Net}

Arsitektur U-Net memiliki ciri khas berbentuk huruf U simetri. Arsitektur ini memperkenalkan layer concatenate pada setiap level untuk mentransfer informasi spasial dari encoder ke decoder secara multilevel.

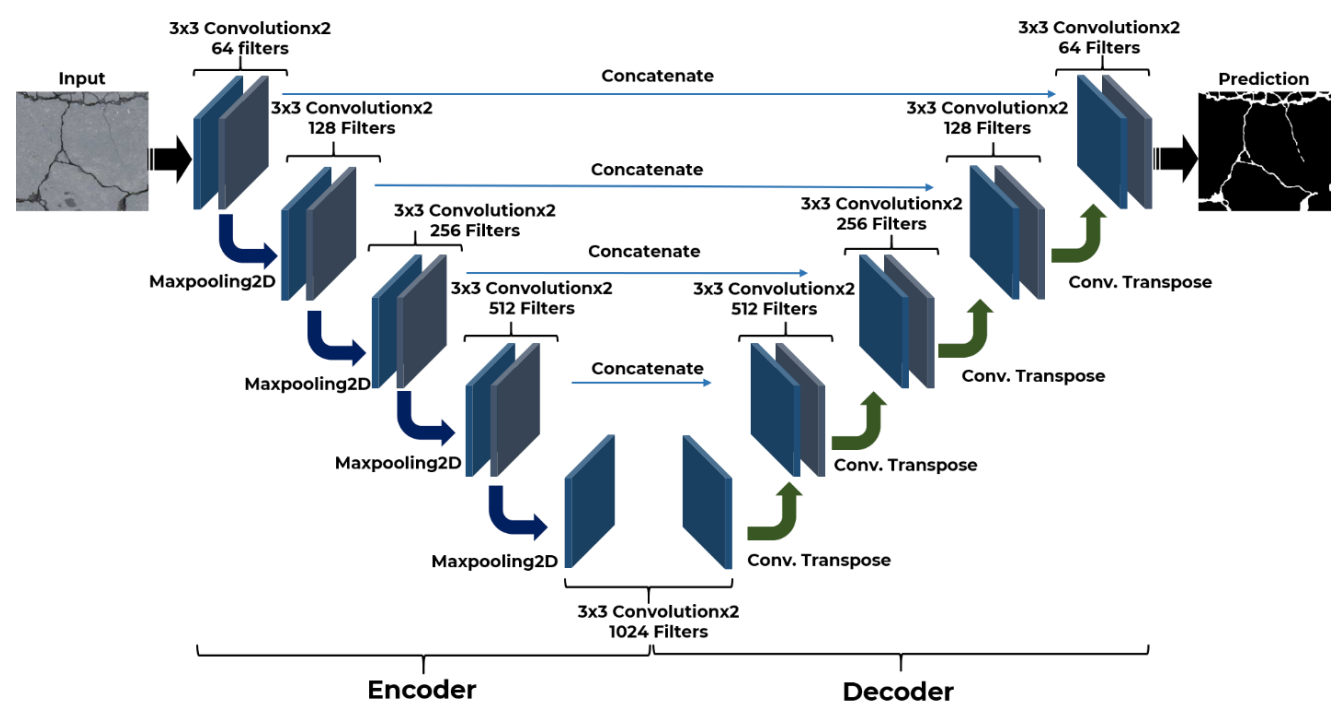

Gambar 1. Arsitektur U-Net 
Fitur concatenate multilevel ini menghasilkan segmentasi gambar yang halus dan akurat. Encoder U-Net terdiri dari layer convolution2D dengan kernel $3 \times 3$ dan maxpooling dengan kernel $2 \times 2$. Jumlah filter convolution2d dilipatgandakan dari 64 filter di layer pertama menjadi 1024 filter di layer bottleneck. Decoder U-Net terdiri dari layer convolution2d dengan kernel $3 \times 3$ dan transpose convolution atau deconvolution dengan kernel $2 \times 2$ dan striding 2. Layer dropout [5] dengan nilai $0,1-0,3$ juga ditambahkan untuk mencegah overfitting dan meregularisasi neural network. Jumlah filter pada decoder sama seperti encoder. Ilustrasi dari U-Net dapat dilihat pada Gambar 1.

\section{Arsitektur DeepLabV3+}

Arsitektur DeepLabV3+ dikembangkan untuk mengatasi kekurangan dari arsitektur DeepLabV3 [6]. DeepLabV3 menggunakan naïve decoder dengan conditional random field (CRF). Naïve decoder ini memiliki beban komputasi yang besar dengan lokalisasi yang kurang akurat. DeepLabV3+ menggunakan backbone Xception [7] yang dimodifikasi dan modul atrous spatial pyramid pooling (ASPP) sebagai encoder. Low level feature map dari Xception digabungkan dengan output ASPP untuk menghasilkan lokalisasi multiskala yang akurat. Decoder DeepLabV3+ terdiri dari convolution2d deengan kernel $3 \times 3$ dan upsampling2d bilinear dengan nilai perbesaran 4. Layer convolution2d pada decoder memiliki jumlah filter 256. Layer dropout bernilai 0,1-0,3 juga ditambahkan pada arsitektur ini untuk regularisasi pelatihan. Ilustrasi dari DeepLabV3+ dapat dilihat pada Gambar 2.

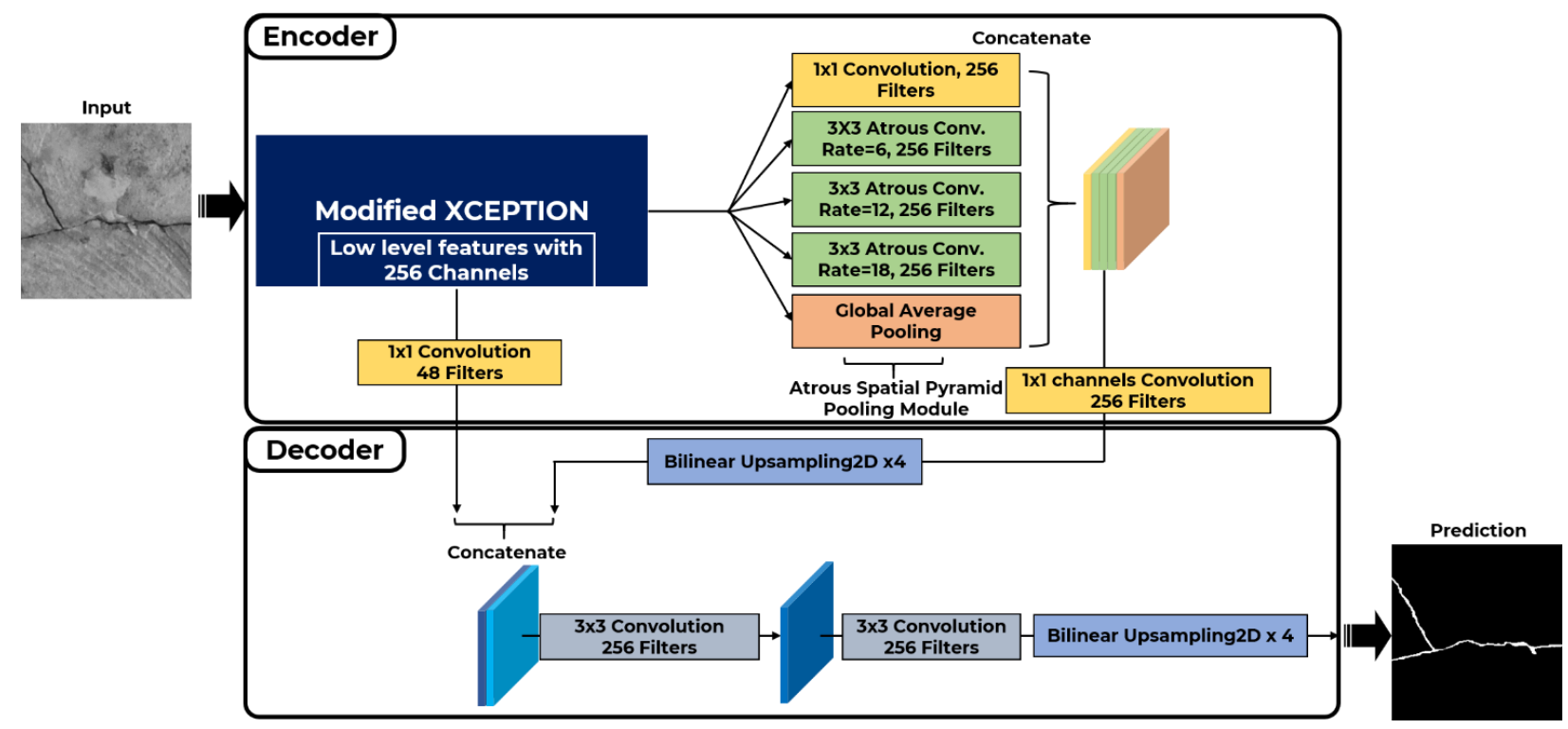

Gambar 2. Arsitektur DeepLabV3+

\section{Optimizer dan Fungsi Loss}

Proses pelatihan akan menggunakan optimizer Adaptive Moment Estimation (Adam) [9] dan fungsi dice loss [10]. Optimizer Adam telah banyak digunakan pada berbagai image recognition task dan telah terbukti sebagai salah satu optimizer dengan konvergensi terbaik dan tercepat. Dice loss telah terbukti memiliki konvergensi yang jauh lebih cepat dibandingkan fungsi crossentropy umum. Fungsi Dice loss memperhatikan kelas dengan area yang lebih kecil, dimana hal ini berkaitan langsung dengan highly unbalanced segmentation. Retak pada permukaan memiliki area yang relatif jauh lebih kecil dibanding latar belakang. Dice loss secara langsung membuat variabel retak sebagai parameter utama dalam persamaannya. Fungsi Adam dapat dilihat pada Persamaan (1)-(3), sedangkan fungsi dice loss dapat dilihat pada Persamaan (4). 


$$
\begin{array}{r}
\hat{s}_{j}^{i}=\frac{\rho_{1} s_{j}^{i-1}+(1-\rho 1) g_{j}}{1+\rho_{1}} \\
\hat{r}_{j}^{i}=\frac{\rho_{2} r_{j}^{i-1}+\left(1-\rho_{2}\right)\left(g_{j}\right)^{2}}{1+\rho_{2}} \\
W_{j}^{i+1}=W_{j}^{i}+\frac{\epsilon \hat{s}_{j}}{\delta+\sqrt{\hat{r}_{j}}}
\end{array}
$$

dengan $W$ adalah pembaruan dari parameter weight, $\varepsilon$ adalah learning rate, $\delta$ adalah konstanta bernilai $10^{-7}$ untuk mencegah fungsi yang tidak terdefinisi, $\rho_{1}$ dan $\rho_{2}$ adalah hyperparameter untuk estimasi momen, dan $g_{j}$ adalah gradien stokastik pada langkah pembelajaran tertentu. Pada studi ini, nilai learning rate untuk U-Net diambil sebesar $4 \times 10^{-4}$ dengan batch size 8 , sedangkan nilai learning rate untuk DeepLabV3+ diambil sebesar $2 \times 10^{-4}$ dengan batch size 4 . Nilai learning rate dan batch diambil sedemikian rupa agar penurunan gradien yang dihasilkan kedua arsitektur maksimal.

$$
D L=1-F 1=1-\frac{2 \times T P+\gamma}{2 \times T P+F N+F P+\gamma}
$$

dengan TP adalah true positives, FN adalah false negatives, FP adalah false positives, dan y adalah faktor smoothening bernilai 1 untuk mencegah fungsi yang tidak terdefinisi.

\section{METODOLOGI}

\section{Dataset Pelatihan}

Kedua arsitektur di atas dilatih menggunakan 2 jenis dataset, yaitu dataset eksternal dan dataset gabungan. Penjelasan mengenai dataset eksternal dan dataset gabungan adalah sebagai berikut:

a. Dataset eksternal bersumber dari Yang, et al. (2018). Dataset eksternal terdiri dari beberapa kategori jenis retak dengan skema warna yang berbeda-beda. Gambar retak pada dataset eksternal memiliki lingkungan dan fitur permukaan yang relatif sederhana. Seperti yang terlihat pada Gambar 3, dataset eksternal tidak mengandung foto permukaan beton yang memiliki void. Dataset eksternal terdiri dari 776 gambar RGB beserta label yang berkaitan. Gambar RGB pada dataset ini memiliki rentang DPI dari 72 hingga 300.

b. Dataset gabungan terdiri atas dataset eksternal yang diambil dari Yang, et al. (2018) dan dataset internal yang dibuat sendiri. Dataset internal diambil menggunakan smartphone Samsung Galaxy Note 8 dengan resolusi kamera 9,1 Mega-Pixels dan bukaan diafragma f/1.7. Foto diambil menggunakan rasio 1 : 1 yang kemudian direduksi ukurannya menjadi $256 \times 256$ piksel. Foto-foto yang telah diambil dilabelkan menggunakan software Adobe Photoshop CC 2017. Retak dilabelkan dengan warna putih yang berkomposisi 255 red, 255 green, dan 255 blue, sedangkan foreground dilabelkan sebagai warna hitam ( 0 red, 0 green, dan 0 blue). Ilustrasi dari proses pembuatan label dapat dilihat pada Gambar 4. Untuk mencegah bias yang tinggi karena keterbatasan data, dataset internal akan diperbanyak menggunakan teknik dataset augmentation. Dataset augmentation yang dipakai adalah rotasi $90^{\circ}$ sebanyak 3 kali. Secara lugas, satu gambar akan diaugmentasi menjadi 4 gambar baru. llustrasi dari data augmentation dapat dilihat pada Gambar 5. Dataset internal disusun sebanyak 35 gambar yang kemudian diaugmentasi menjadi 140 gambar. Maka, total dataset internal adalah 140 gambar permukaan beton silinder yang memiliki retak dan void. Dataset internal yang dibuat digabungkan dengan dataset eksternal menjadi dataset gabungan. Maka, dataset gabungan memiliki total 916 gambar.

\section{Parameter Evaluasi}

Model akan dievaluasi menggunakan parameter akurasi, F1 [8], precision dan recall. F1 adalah nilai seimbang antara precision dan recall. F1 akan dijadikan parameter perbandingan utama 
karena F1 memiliki fungsi yang hanya memperhitungkan error satu kelas yang ditentukan. Akurasi tidak akan dijadikan parameter pembanding utama karena hasil akurasi akan cenderung berorientasi pada kelas yang lebih besar, yaitu foreground. Model U-Net dan model DeepLabV3+ yang telah dilatih dengan dataset eksternal akan dievaluasi untuk mendeteksi retak pada gambargambar dataset eksternal dan dataset gabungan. Hal yang sama juga dilakukan untuk model UNet dan model DeepLabV3+ yang dilatih menggunakan dataset gabungan.
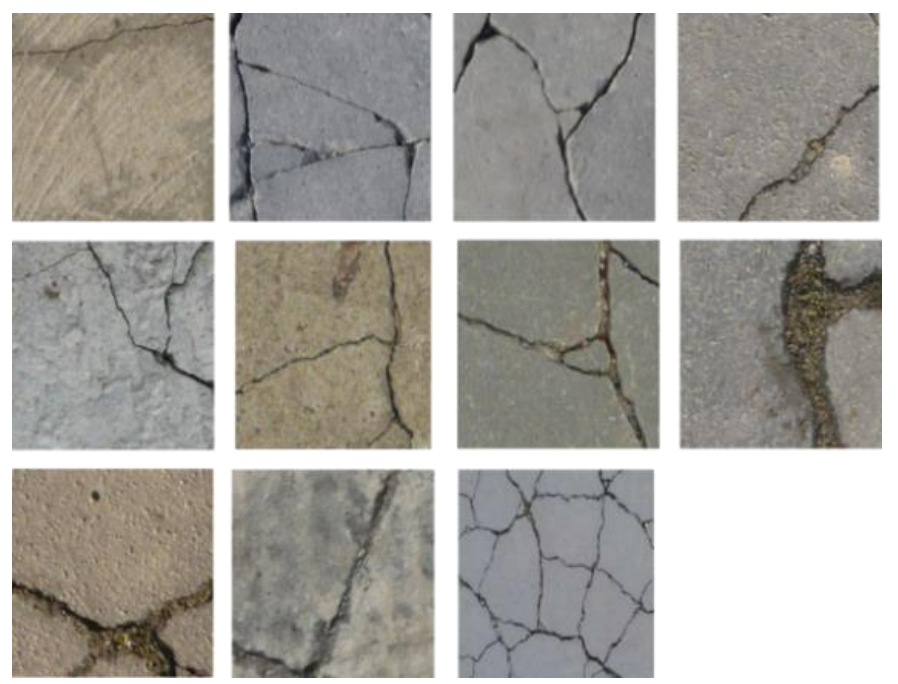

Gambar 3. Jenis Lingkungan Retak pada Dataset Eksternal

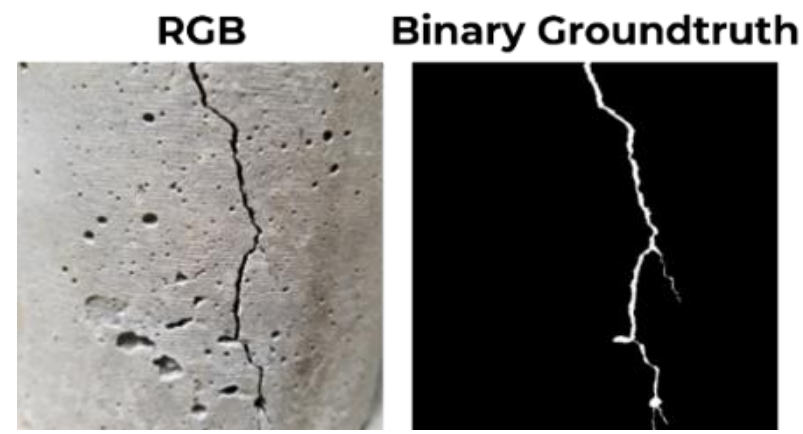

Gambar 4. Contoh Pasangan Dataset Internal (RGB Input dan Groundtruth Biner)
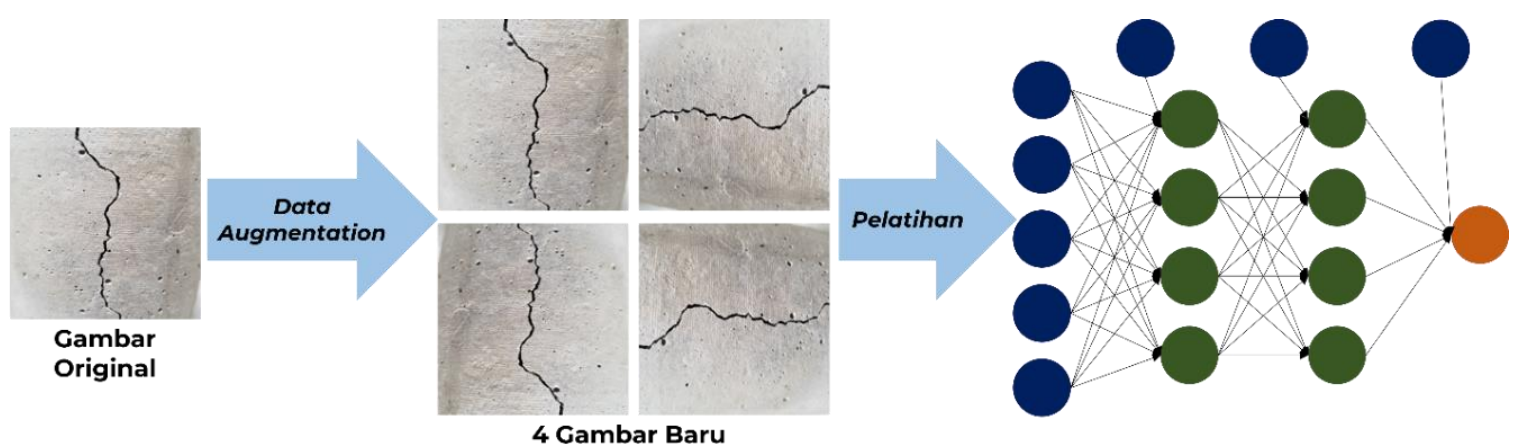

Gambar 5. Data Augmentation

\section{Konfigurasi Pelatihan}

Data gambar akan melalui proses normalisasi terlebih dahulu. Nilai piksel akan dibagi 255 agar piksel bernilai $0-1$. Hal ini diperlukan untuk mempermudah konvergensi neural network dan menyesuaikan data input dengan nilai probabilitas dari layer output. Kemudian, semua gambar akan diubah ukurannya menjadi 256×256 piksel. Nilai 256 dipakai untuk menyesuaikan angka 
komputasi dengan bit komputer yang bernilai $2^{n}$. Proses komputasi akan menjadi lebih cepat jika data komputasi bernilai $2^{\text {n }}$.

Data akan dibagi menjadi $80 \%$ pelatihan dan $20 \%$ validasi dengan konfigurasi 5 -fold crossvalidation. Proses pembagian ini diperlukan untuk mencegah kasus high variance atau overfitting. High variance adalah kasus dimana fungsi polinomial neural network memiliki derajat terlalu tinggi sehingga mengabaikan konteks regresi yang sebenarnya. Model akan dilatih sebanyak 70 epoch menggunakan checkpoint untuk menyimpan model dengan nilai F1 terbaik.

Model akan dilatih pada fasilitas cloud computing menggunakan perangkat keras graphic processing unit NVIDIA Tesla V100 dengan random access memory 27,4 gigabyte. Framework yang digunakan adalah Tensorflow 2.3.0 dengan dukungan Keras 2.4.3. Tensorflow adalah salah satu high level sekaligus low level API untuk machine learning, sedangkan Keras adalah salah satu high level API untuk machine learning yang menjadi backbone bagi tensorflow.

\section{HASIL PELATIHAN DAN PEMBAHASAN}

Hasil pelatihan dengan dataset eksternal telah dibahas pada penelitian sebelumnya [4], sedangkan hasil kurva pelatihan dengan dataset gabungan dapat dilihat pada Gambar 6. Garis putus-putus menunjukkan tren validasi, sedangkan garis tegas menunjukkan tren pelatihan. Konvergensi U-Net digambarkan dengan garis hijau, sedangkan konvergensi DeepLabV3+ digambarkan dengan garis ungu. Garis pelatihan dan garis validasi yang berdekatan mengindikasikan bahwa model tidak overfitting. Hasil akhir checkpoint dapat dilihat pada Tabel 1. U-Net memiliki nilai F1, akurasi, precision, dan recall masing-masing sebesar $85,92 \%, 96,36 \%$, $91,08 \%$, dan $84,70 \%$, sedangkan DeepLabV3+ memiliki nilai F1, akurasi, precision, dan recall masing-masing sebesar $84,09 \%, 96,16 \%, 81,98 \%$, dan $88,77 \%$. Berdasarkan parameter $\mathrm{F} 1$ yang merupakan parameter pembanding utama, U-Net berperforma lebih baik dari DeepLabV3+. Hasil dari akurasi kedua arsitektur bernilai di atas $90 \%$. Hal ini terjadi karena nilai akurasi akan berorientasi pada jumlah kelas yang lebih besar, yaitu jumlah piksel foreground yang benar atau true negative. Nilai precision yang lebih tinggi dari recall mengindikasikan bahwa hasil prediksi model cenderung memiliki lebih sedikit false positive, dimana false positive adalah nilai prediksi retak yang tidak sesuai dengan label. U-Net memiliki hasil precision lebih tinggi dari recall, sedangkan DeepLabV3+ memiliki hasil recall lebih tinggi dari precision. Oleh karena itu, dapat disimpulkan bahwa U-Net lebih banyak membuat prediksi negatif yang tidak sesuai dengan label, sedangkan DeepLabV3+ lebih banyak membuat prediksi positif yang tidak sesuai dengan label.
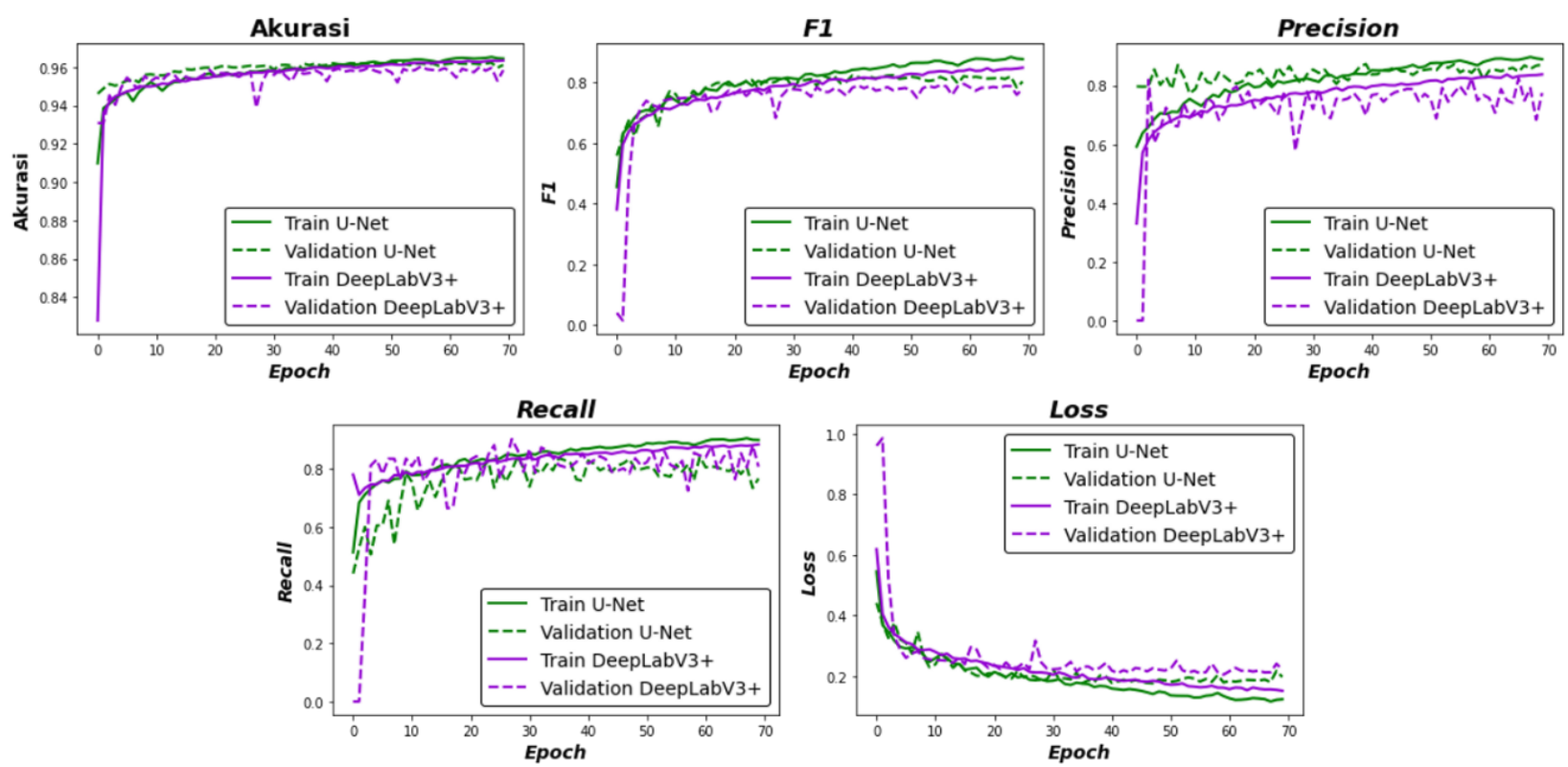

Gambar 6. Hasil Pelatihan dengan Dataset Gabungan 
Berdasarkan Tabel 1, dapat dilihat bahwa model yang hanya dilatih menggunakan dataset eksternal hanya memiliki nilai $\mathrm{F} 1$ sebesar $75,71 \%$ dan $76,47 \%$ masing-masing untuk U-Net dan DeepLabV3+ saat di tes menggunakan dataset gabungan. Nilai ini berbeda jauh saat model dites dengan dataset eksternal, dimana U-Net memiliki nilai F1 sebesar $87,31 \%$ dan DeepLabV3+ memiliki nilai $\mathrm{F} 1$ sebesar $87,12 \%$. Hal ini menunjukkan bahwa foto beton ber-void pada dataset gabungan memberikan dampak negatif pada performa model yang hanya dilatih dengan dataset eksternal. Oleh karena itu, diperlukan feature engineering pada dataset pelatihan, yaitu melatih model dengan dataset gabungan. Setelah model dilatih dengan dataset gabungan, nilai $\mathrm{F} 1$ mengalami peningkatan performa secara signifikan. Nilai F1 meningkat menjadi $85,92 \%$ dan $84,09 \%$ masing-masing untuk U-Net dan DeepLabV3+ saat di tes menggunakan dataset gabungan. Saat dievaluasi terhadap dataset eksternal pada model ini memiliki nilai $\mathrm{F} 187,72 \%$ dan $85,54 \%$ masing-masing untuk U-Net dan DeepLabV3+, dimana hasil ini relatif sama dengan model yang hanya dilatih dengan dataset eksternal.

Tabel 1. Hasil Evaluasi Model

\begin{tabular}{lcc}
\hline & Tes Eksternal & Tes Gabungan \\
\hline & Akurasi $=96,32 \%$ & Akurasi $=93,34 \%$ \\
Pelatihan U-Net (Eksternal) & $\mathrm{F} 1=87,31 \%$ & $\mathrm{~F} 1=75,71 \%$ \\
& Precision $=86,54 \%$ & Precision $=69,97 \%$ \\
& Recall $=90,05 \%$ & Recall $=88,38 \%$ \\
Pelatihan DeepLabV3+ (Eksternal) & Akurasi $=96,41 \%$ & $\mathrm{Fkusi}=93,68 \%$ \\
& $\mathrm{~F} 1=87,12 \%$ & $\mathrm{~F} 1=76,47 \%$ \\
& Precision $=84,79 \%$ & Precision $=70,94 \%$ \\
& Recall $=90,42 \%$ & Recall $=87,64 \%$ \\
Pelatihan U-Net (Gabungan) & Akurasi $=96,48 \%$ & Akurasi $=96,36 \%$ \\
& $\mathrm{~F} 1=87,72 \%$ & $\mathrm{~F} 1=85,92 \%$ \\
& Precision $=89,80 \%$ & Precision $=91,08 \%$ \\
& Recall $=87,71 \%$ & Recall $=84,70 \%$ \\
Pelatihan DeepLabV3+ (Gabungan) & Akurasi $=96,19 \%$ & Akurasi $=96,16 \%$ \\
& $\mathrm{~F} 1=85,54 \%$ & $\mathrm{~F} 1=84,09 \%$ \\
& Precision $=81,58 \%$ & Precision $=81,98 \%$ \\
& Recall $=90,84 \%$ & Recall $=88,77 \%$ \\
\hline
\end{tabular}

Untuk evaluasi lebih lanjut, maka akan dilakukan pengujian model. Pengujian dilakukan menggunakan dataset eksternal dan dataset internal. Hasil pengujian pada model yang dilatih dengan dataset eksternal dapat dilihat pada Gambar 7. Baik U-Net atau DeepLabV3+ dapat mensegmentasi retak dengan baik pada dataset eksternal. Namun, kedua model ini masih menganggap void sebagai retak pada dataset internal. Hal ini mungkin disebabkan karena model masih menganggap retak sebagai fungsi dari intensitas warna secara sederhana. Model belum memperhitungkan fitur kompleks yang seharusnya dijadikan filter atau kernel utama dalam layer convolution. Hasil yang kurang baik dari model ini berbanding lurus dengan nilai $\mathrm{F} 1$ (75,71\% dan $76,47 \%$ ) yang kurang baik saat dites dengan dataset gabungan. Hasil pengujian pada model yang dilatih dengan dataset gabungan dapat dilihat pada Gambar 8. Baik U-Net atau DeepLabV3+ dapat membedakan void dengan retak. Hasil ini sesuai dengan peningkatan nilai F1 yang telah dibahas di atas. Penambahan dataset internal juga tidak mempengaruhi kualitas segmentasi pada dataset eksternal. Hal ini tercermin dari nilai F1 yang relatif sama dengan model sebelumnya saat diuji dengan dataset eksternal. Semua foto yang digunakan untuk pengujian adalah foto validasi agar hasil tidak memiliki bias. 


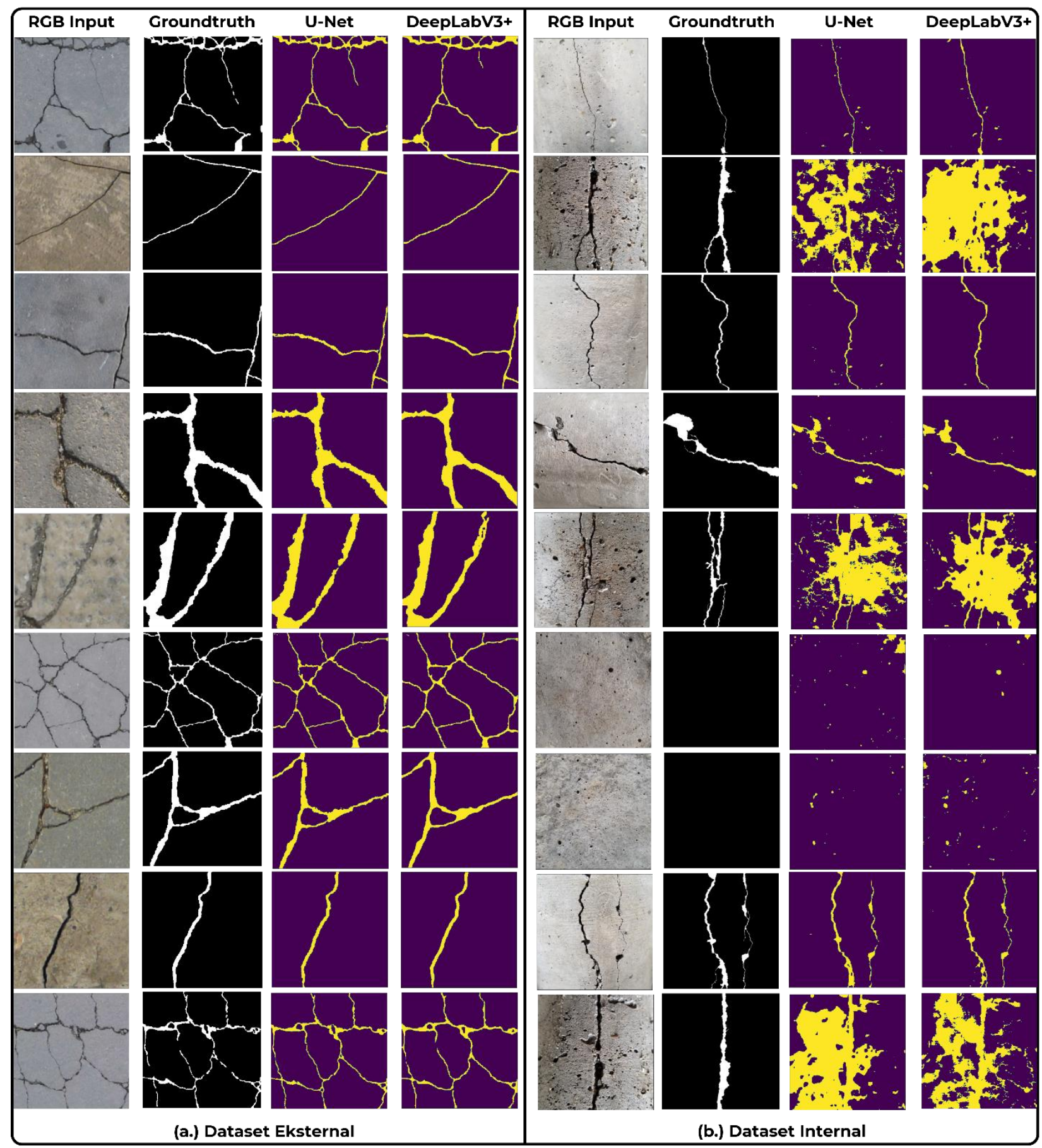

Gambar 7. Hasil Pengujian Model yang Dilatih dengan Dataset Eksternal 


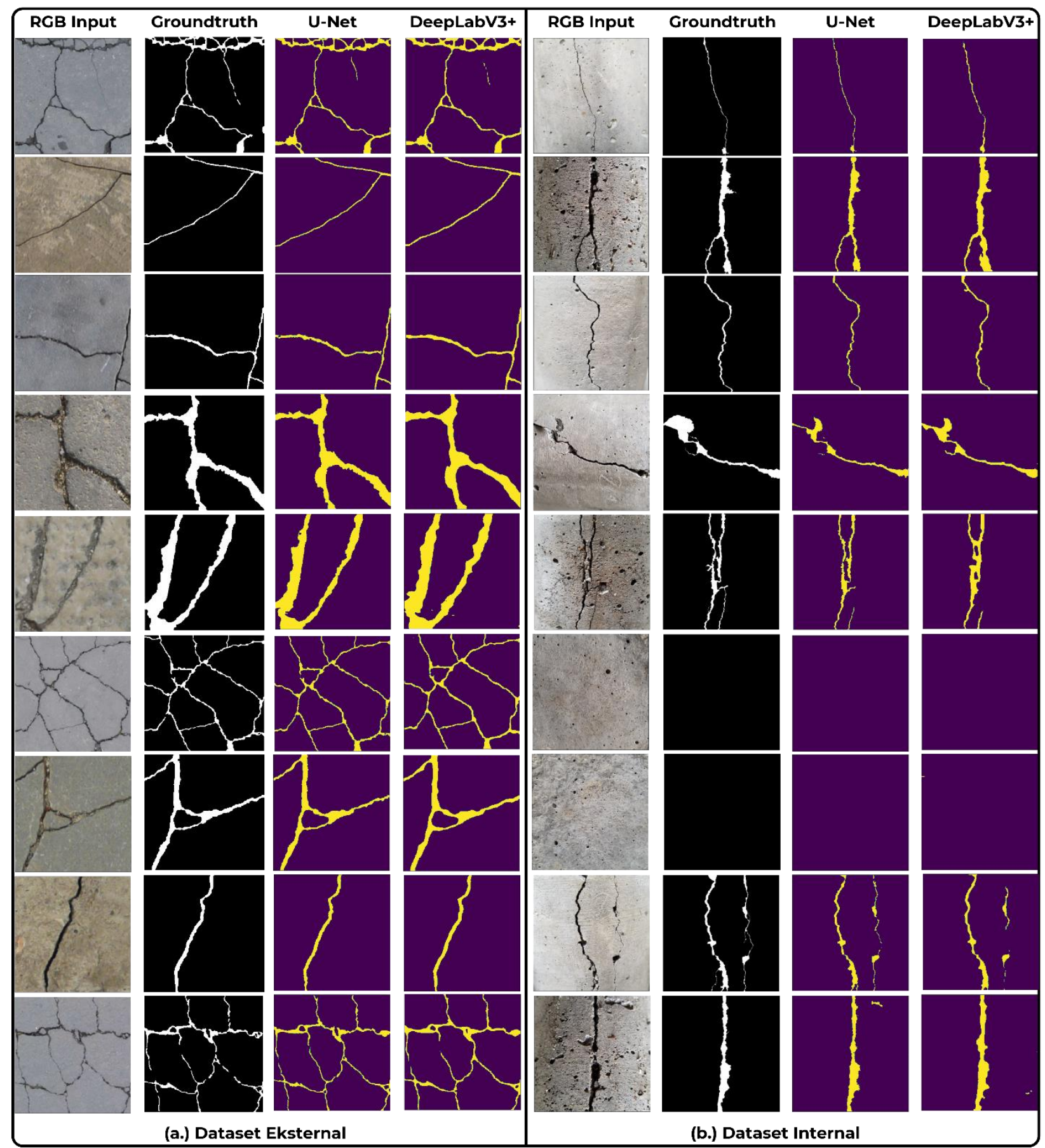

Gambar 8. Hasil Pengujian Model yang Dilatih dengan Dataset Gabungan

Terdapat sebuah keterbatasan pada model yang dilatih menggunakan dataset gabungan. Model terkadang menganggap void yang berbentuk memanjang seperti retak sebagai retak. Seperti yang terlihat pada Gambar 9, void yang berbentuk memanjang dan berliku seperti retak dianggap sebagai retak oleh model. Hal ini cukup umum terjadi pada pengujian neural network dimana seringkali terdapat bias yang susah dihindari. Namun, mengingat data yang digunakan sangat terbatas, dapat diambil kesimpulan bahwa neural network berperforma sangat baik dalam membedakan void dengan retak untuk keseluruhan dataset. 


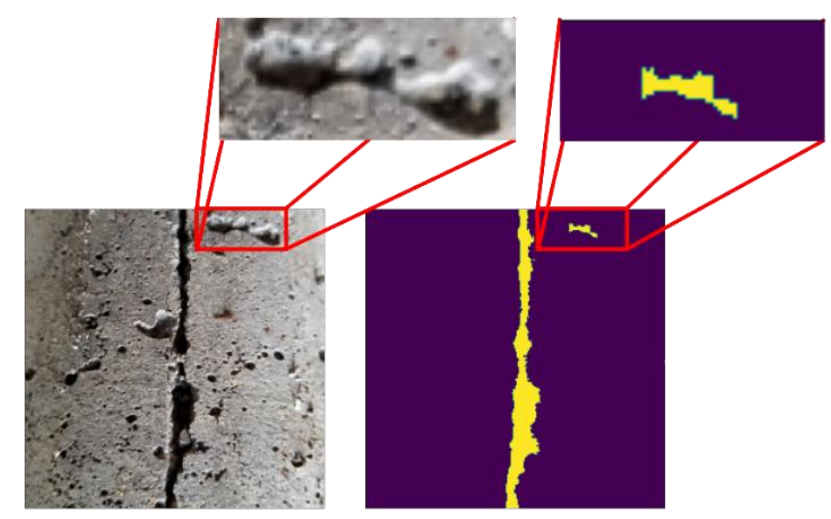

Gambar 9. Void Berbentuk seperti Retak Seringkali Terdeteksi sebagai Retak

\section{SIMPULAN}

Penelitian ini mengimplementasikan sistem deteksi retak permukaan beton menggunakan dua arsitektur encoder-decoder CNN, yaitu U-Net dan DeepLabV3+. Terdapat keterbatasan pada dataset eksternal yang dipakai penelitian sebelumnya, yaitu void permukaan seringkali terdeteksi sebagai retak. Oleh karena itu, dataset internal yang secara khusus membedakan void dengan retak disusun. Dataset internal digabungkan dengan dataset eksternal menjadi dataset gabungan, yang kemudian digunakan untuk melatih neural network dan dievaluasi pengaruhnya terhadap nilai F1 dan hasil prediksi. Berdasarkan hasil pelatihan dan evaluasi, dapat diambil kesimpulan sebagai berikut:

1) Peningkatan nilai F1 menunjukkan bahwa penambahan dataset internal berpengaruh signifikan pada performa model. Hasil pelatihan menunjukkan bahwa nilai F1 meningkat signifikan setelah penambahan dataset internal. Nilai F1 meningkat dari $75,71 \%$ dan $76,47 \%$ masing-masing untuk U-Net dan DeepLabV3+ menjadi 85,92\% dan 84,09\% masing-masing untuk U-Net dan DeepLabV3+ saat dievaluasi menggunakan dataset gabungan.

2) Berdasarkan gambar hasil pengujian, penambahan dataset pelatihan internal yang terdiri dari foto beton ber-void berhasil meningkatkan kemampuan model untuk membedakan retak dengan void, baik pada arsitektur U-Net atau arsitektur DeepLabV3+.

3) U-Net berperforma lebih baik dari DeepLabV3+. Hal ini dapat dilihat pada nilai F1 kedua arsitektur. Model U-Net yang dilatih baik menggunakan dataset eksternal ataupun dataset gabungan memiliki nilai F1 yang lebih tinggi dari model DeepLabV3+.

\section{DAFTAR RUJUKAN}

[1] O. Ronneberger, P. Fischer, dan T. Brox, "U-Net: Convolutional Networks for Biomedical Image Segmentation," In International Conference on Medical image computing and computer-assisted intervention, 2015, hal. 234-241, doi: 10.1007/978-3-319-24574-4_28.

[2] L. C. Chen, Y. Zhu, G. Papandreou, F. Schroff, dan H. Adam, "Encoder-Decoder with Atrous Separable Convolution for Semantic Image Segmentation," In Proceedings of the European conference on computer vision (ECCV), 2018, hal. 801-818.

[3] X. Yang, H. Li, Y. Yu, X. Luo, T. Huang, dan X. Yang, "Automatic Pixel-Level Crack Detection and Measurement Using Fully Convolutional Network," Computer-Aided Civil and Infrastructure Engineering, vol. 33, no. 12, hal. 1090-1109, 2018, doi: 10.1111/mice.12412.

[4] P.N. Hadinata, D. Simanta, L. Eddy, dan K. Nagai, "Crack Detection on Concrete Surfaces Using Deep Encoder-Decoder Convolutional Neural Network: A Comparison Study Between U-Net and DeepLabV3+," Journal of the Civil Engineering Forum, vol. 7, no. 3, 2021.

[5] N. Srivastava, G. Hinton, A. Krizhevsky, I. Sutskever, dan R. Salakhutdinov, "Dropout: A Simple Way to Prevent Neural Networks from Overfitting," The journal of machine learning research, vol. 15, no. 1, hal. 1929-1958, 2014. 
[6] L. C. Chen, G. Papandreou, F. Schroff, dan H. Adam, "Rethinking Atrous Convolution for Semantic Image Segmentation," 2017, arXiv preprint arXiv:1706.05587.

[7] F. Chollet, "Xception: Deep Learning with Depthwise Separable Convolutions," In Proceedings of the IEEE conference on computer vision and pattern recognition, 2017, hal. 1251-1258.

[8] C. Goutte, dan E. Gaussier, "A Probabilistic Interpretation of Precision, Recall And F-Score, With Implication for Evaluation," In European conference on information retrieval, 2005, hal. 345-359, doi: 10.1007/978-3-540-31865-1_25.

[9] D. P. Kingma, dan J. Ba, "Adam: A Method for Stochastic Optimization," 2014, arXiv preprint arXiv:1412.6980.

[10] F. Milletari, N. Navab, dan S. A. Ahmadi, "V-Net: Fully Convolutional Neural Networks for Volumetric Medical Image Segmentation," In 2016 fourth international conference on 3D vision (3DV), 2016, hal. 565-571, doi: 10.1109/3DV.2016.79. 